\title{
Depositional Hydrology in the Subtidal Site of Fertilizer Company: Grain-size Hydraulics Approach
}

\author{
I.D. Edem*, U.C. Udo-Inyang \\ Department of Soil Science and Land Resources Management, University of Uyo, Akwa Ibom \\ State, Nigeria.
}

${ }^{*}$ Corresponding author: dennis.edem@gmail.com +234-802-703-1426

Keywords: Sediment, Environment, Deposition, grain-Size, Pollution, Fertilizer

\begin{abstract}
Still very much terra incognita, grain shape has the potential to evaluate sedimentary transport, provenance, and depositional environments. There are several standard measures of grain shape. The results revealed that, the soil is non-uniformly graded with tortuous pore geometry due to overlaying layers, even though the grain size varied from granular grained size to medium grained. Therefore the soil under study is not easily moved by transporting medium. Also, there is significant effect of redox potential (ORP) on the electron availability of nitrate and the tested heavy metals $(\mathrm{Cd}, \mathrm{Ni}, \mathrm{Pb}$, and $\mathrm{Cu})$ were below detection limit of analytical equipment. The least reduced conditions occurred in stations; 2 (control), 3, 6, 15, 18 and 19 with minimum values of 99 to $110 \mathrm{mv}$. The absence of significant fungi populations in the soil indicates that the soils have no potential to biodegrade hydrocarbons when they are released into the environment.
\end{abstract}

\section{INTRODUCTION}

Soil is a three phase system which plays different roles in the biosphere, such as: i) regulation of biogeochemical cycles, ii) microorganism habitat and iii) medium for plant roots [1]. Another soil function, particularly of its pores, is to store and conduct fluids like water and air. The latter is relevant not only to crop production [2], but also to environmental protection as indicated by Ball et al., [3] when they refer to the effect of soil compaction due to grain-sizes. Grain-size hydraulics is a function of the grain diameter (d) squared. As such, a useful grain-size comparison involves $\log _{2}$ of the grain size. Shakoor and Cook [4] used this information to develop the phi scale. phi $(\varnothing)=$ $\log _{2} \mathrm{~d}$ (where $\mathrm{d}$ is the diameter in $\mathrm{mm}$ ). It is important to note that as grain-size gets smaller, phi gets bigger as well as the level of contamination in the environment. The quality of life on earth is linked undeniable to the overall quality of the environment [5]. Pollution of the biosphere by effluent discharge due to industrial, agricultural and domestic activities has created a serious problem for the safe and rational utilization of soil [6]. This problem according to Edem and Udoinyang [7] is very severe in the coastal region, when tidal fluctuations bring discharges from industrial areas and deposit them on soils; this accentuates the already existed problem on soil and is considered to be a major constraint to agricultural production in coastal areas.

These anthropogenic activities contribute significantly to the level of pollution and to the preponderance of pathogenic disease carrying organisms which are extremely dangerous to health. Several researchers using isolation-based technique have demonstrated that assessing the level of contamination can cause a shift in the actual concentration of the pollutants on soil $[8,9,10$, and 11]. This therefore, calls for the use of grain-size hydraulic where the concept of the distance to a point in the spatio-temporal variation can be easily handled.

Statistics of the grain-size distribution is a computer calculated module with a U.S. Geological Survey Marine Geology grain-size program, in which the grain-size statistical parameters and graphic representations are given in phi units. This method gives a more rigorous treatment of the soil and sediment characteristics. The first moment measured corresponds to the mean, the second to the standard deviation, the third to the skewness, and the fourth to the kurtosis .

Apart from the sediment characteristics, information about source materials, the depositional environment, and other physical and chemical factors can be provided. In this present study, the 
distribution of unconsolidated sediment and depositional hydrology in a subtidal site of a fertilizer company were assessed on phi scale.

\section{MATERIALS AND METHODS}

\section{Site description and Environment of the study site}

The study was conducted at the site of National Fertilizer Company of Nigeria (NAFCON) at Onne, located at latitude $4^{\circ} 33^{1} \mathrm{~N}$ and longitude $7^{\circ} 27^{1} \mathrm{E}$ in Port Harcourt city of Southeastern Nigeria. Port Harcourt is the capital of Rivers State, on the Bonny River, in the Niger Delta. The city is a leading port of the country, a road and rail hub, and a major industrial center. Its exports include palm oil, petroleum, coal, tin, columbite, cocoa, and peanuts. Port Harcourt has prospered as the regional headquarters for the petroleum industry. It has a large petroleum refinery and storage facilities. Other industries of the area include sawmilling, Fertilizer Company, automobile assembly, food canning, tobacco processing, and the manufacture of rubber, glass, metal, paper products, cement, tires, and beer. The local fishing industry is also important to the city's economy.

Located in the city are the University of Port Harcourt (1975) and Rivers State University of Science and Technology (1971). While the Ijaw people are dominant in the region, the city itself is ethnically diverse. The port was established by the British in 1915 and it serves both eastern Nigeria and parts of northern Nigeria. Port Harcourt Population estimate is over 5,198,716 [12]

\section{THE SOIL TYPE AND SAMPLING STRATEGY}

In view of the fact that the environmental features are fairly more uniform over large areas, grid densities were widely spaced. Nevertheless, $80 \%$ of the samples were collected within the project area. The remaining $20 \%$ were obtained from the surrounding ecosystems with sufficient buffer, and these samples served as controls.

The soil type of the area is Ultisol and is classified as Typic Paleudult (USDA) [13] having soil units intricately associated together that they cannot be demarcated from the other except in very detailed soil survey. Even though the geomorphic units have relatively uniform parent materials, the near flatness of the area renders surface recognition of likely boundaries between soil units difficult. In some locations, especially areas covered by forest type vegetation, mapping boundaries between soils units on the field were extremely difficult and could take a lot of time. No attempt was therefore made to demarcate the soil boundary by taking sufficient soil observations. What was done was to traverse the site and identify as much as possible the major morphological soil units. In this process, a total of twenty sampling stations were fully sampled and profiles extensively described.

Soil samples were collected from randomly selected geo-referenced and spatially distributed spots in the study area along the transect lines at two depths (Surface; 0 to $15 \mathrm{~cm}$ and sub-surface; 15 to $30 \mathrm{~cm}$ ) in each sampling point using a Dutch auger. A total of 17 sampling points were collected (totalling 34 samples for surface and subsurface layers) with auger and stored in labelled polyethylene bags for physico-chemical analysis.

Modal soil profile measuring $1.5 \mathrm{~m} \times 1.0 \mathrm{~m}$ with a depth of $1 \mathrm{~m}$ was dug at 3 geo-referenced locations and three generic horizons were identified in each and described on the basis of field morphological characteristics. Soil colour, thickness, depth of penetration, structure, nature of layer boundaries and the presence of mottles or clay movement were assessed with Munsell colour chart, pocket penetrometer, visual observations and by feel respectively.

The samples were qualitatively transported to the laboratory for further processes. All samples were chained custody in the field to facilitate tracking of the samples from the field to the laboratory. Grain-size hydraulics method for determining the grain size distribution of clastic particles typically between $2.0 \mathrm{~mm}$ and $0.0625 \mathrm{~mm}$ (from coarse silt to coarse sand) was employed for determining depositional hydrology and the information used to developed the phi scale for refining sedimentary environments. 
Data obtained were statistically analysed and t-statistics was used to compare the parameters between the two seasons. Arch-View GIS version 3.1 allotted the deposition on the hyperspace.

\section{RESULTS AND DISCUSSION}

\section{Grain-size statistics and parameters}

Statistics of the grain-size distribution were computer calculated (Tables 4-6) and the parameters were presented in phi unit. All of the statistical parameters were calculated using the method of moments. This method gives a more rigorous treatment of the sediment characteristics. The first moment measured corresponds to the mean, the second to the phi deviation, the third to the skewness, and the fourth to the kurtosis. The results revealed that, the soil is non-uniformly graded with tortuous pore geometry due to overlaying layers, even though the grain size varied from granular grain-size to medium grain. Therefore the soil under study is not easily moved by transporting medium.

Figures $1-3$, showed the particle size distribution curves of different soils. The soils in locations 1(control) and 2 exhibited equal uniformity in shape, irrespective of the actual particle size. The same was true for locations 5 and 9, but the uniformity coefficient of locations 5 and 9 are greater in numerical values (35\%) than locations 1 and 2 (Fig. 1). Location 1 contains the particles of different sizes in good proportion (well graded), whereas locations 5 and 9 indicated coarse grained soils.

Generally, the inclusive graphic standard deviation showed that the grained-size variations of samples were extremely poorly sorted with over 4.0 phi. Also, the curves revealed that location 17 (Figure 2) and 30-60 cm depth of location 8, (L8_60) (Fig 3) have more finer grained soil than locations 10,12 and 20 , and $0-30 \mathrm{~cm}$ of location 8 .

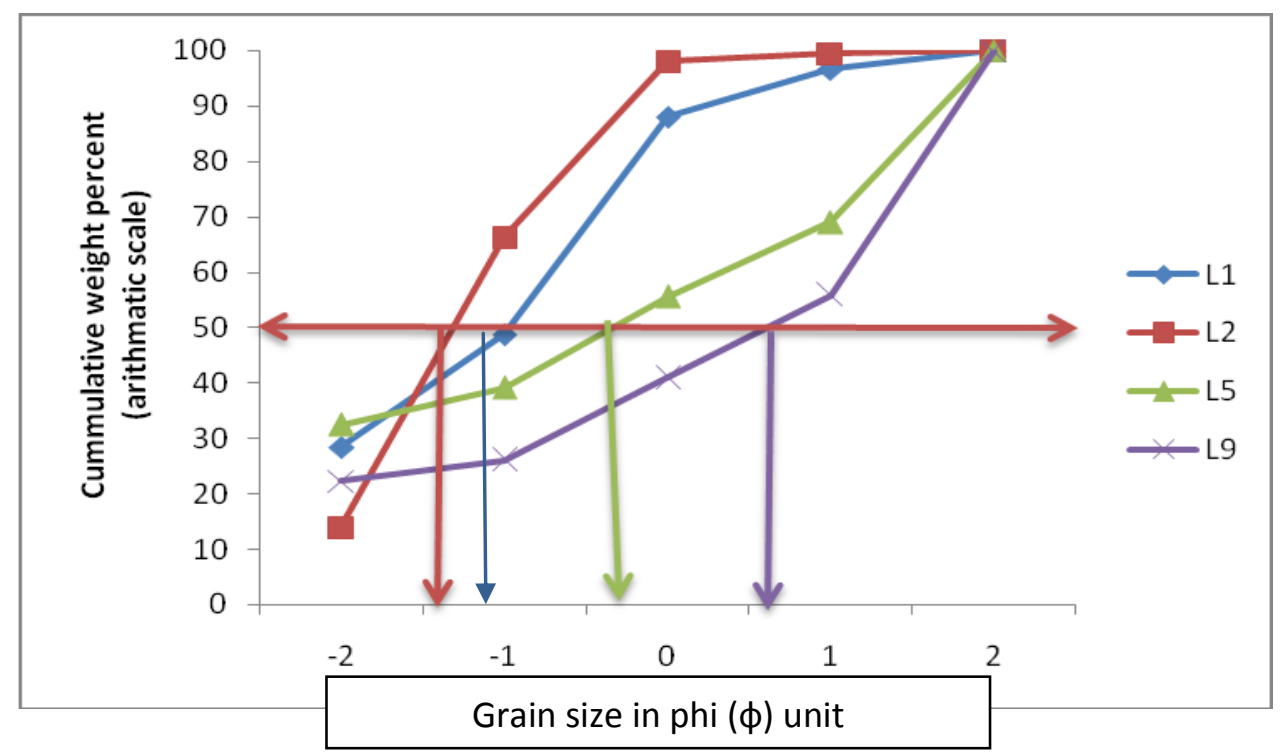

Fig 1. Particle size distribution of soils in locations 1,2,5, and 9 


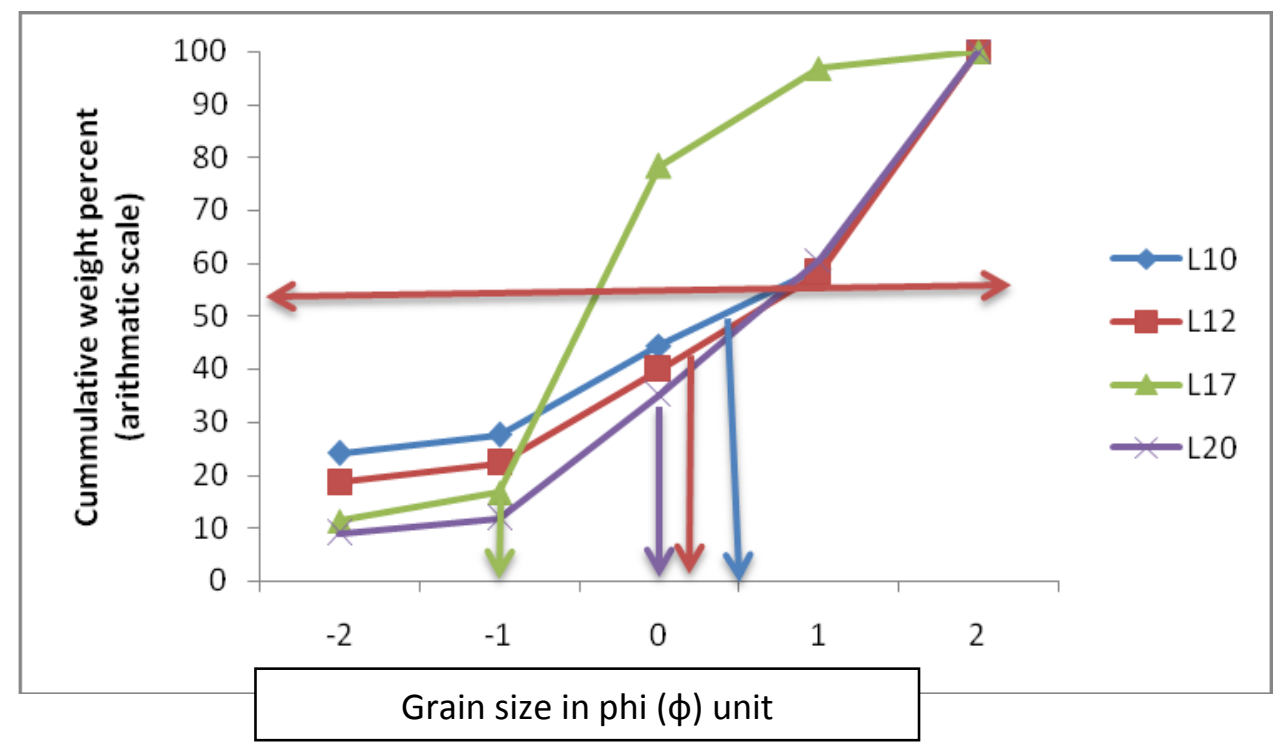

Fig 2. Particle size distribution of soils in locations $10,12,17$, and 20

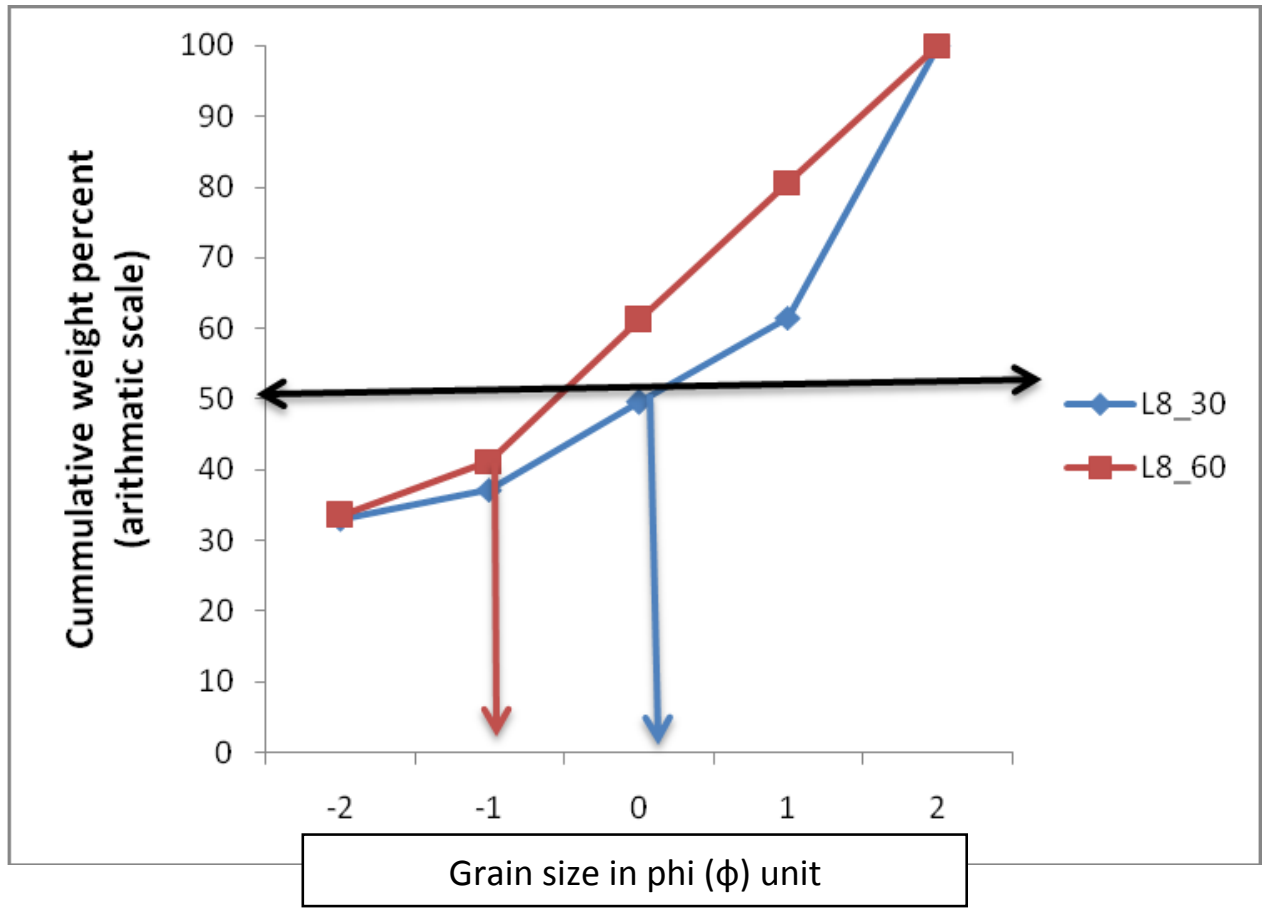

Fig 3. Particle size distribution of soils in location 8 (profile; $0-30$ and $30-60 \mathrm{~cm}$ )

\section{5. pH and Redox potential}

The summary of the soil characteristics in the study are presented in Tables $1-6$. Acidity is generally associated with leached soils; however agricultural practices and other anthropogenic activities do alter soil $\mathrm{pH}$. Soil $\mathrm{pH}$ is often considered in terms of the soil capability and suitability to support plant growth. The $\mathrm{pH}$ of the soils (Table 1) tested ranged from 4.0 (Stations 4, 5, 8, 12, 14 and 17) to 6.4 (Station 3) on the surface, and from 3.9 (stations 5, 17 and 20) to 6.6 (Station 3) in the subsurface soils indicating strongly acidic and slightly acidic soils respectively. The $\mathrm{pH}$ of 4.8 is set as the lower limit for optimum growth of plants, and conversely the $\mathrm{pH}$ greater than 7.5 is regarded as the extreme upper limit (alkalinity) at which some plants can still grow [14. Thus, without any exception, the soils can support plant growth.

The redox potential (ORP) is the single electro-chemical property that serves to distinguish submerged soils from a well drained soil. The ORP of the soil is low and varies from 102.00 to $160.0 \mathrm{mv}$ (averaged; $132.68 \mathrm{mv}$ ) and 99.00 to $169.00 \mathrm{mv}$ (averaged; $127.91 \mathrm{mv}$ ) in surface and 
subsurface layers respectively. According to a scale of ORP measurement proposed by Gee and Or [15], this low potential reflects the poor oxidised state of aerobic media. And this indicates that the quantitative absorption capacity of terrestrial waste of this soil is low. The present status of ORP affect the electron availability of nitrate and the tested heavy metals ( $\mathrm{Cd}, \mathrm{Ni}, \mathrm{Pb}$, and $\mathrm{Cu}$ ) that were below detection limit and indirectly, the availability of phosphorus in the soils. The least reduced conditions occurred in stations 2 (control), 3, 6,15,18 and 19 with minimum values of 99 to 110 mv. The observation in reduced ORP changes may partly be attributed to erratic microbial activity.

\section{ELECTRICAL CONDUCTIVITY}

The electrical conductivity of a soil indicates the total ionic strength of a soil. Low total ionic strength in a soil indicates low dissolved salt contents and vice versa. Consequently Electrical conductivity increases with higher amount of soluble salts. Electrical conductivity values of soils on the surface soil ranged from $18.0 \mu \mathrm{s} / \mathrm{cm}$ (sample station 8) to $204.0 \mu \mathrm{S} / \mathrm{cm}$ (sample station 3), and from $21.0 \mu \mathrm{S} / \mathrm{cm}$ (sample station 2) to $201.0 \mu \mathrm{s} / \mathrm{cm}$ (sample station 3) at the sub surface level of 15 to $30 \mathrm{~cm}$ respectively. The electrical conductivity value of the soil at the surface and subsurface soils ranged from low to moderately high. In conjunction with ORP status (especially in location 3 ), the changes in electrical conductance of the soil solution reflects the balance between reactions that produce ions and those that inactivate them or replace them with slower moving ions. Hence the level for exchange of plant nutrients for optimum growth is moderate, confirming the work of Akinrinde [16]

\section{DISTRIBUTION OF NITROGEN-BASED ORGANIC CONTENT IN THE SOIL.}

In these soils, the main transformations that nitrogen undergoes are the low accumulation of ammonia and nitrogen fixation. Therefore, variation in the concentrations of these $\mathrm{N}$ forms $\left(\mathrm{NH} 4^{+}\right.$, $\mathrm{NO}_{3}{ }^{-}$and $\mathrm{NO}_{2}{ }^{-}$) was erratic. Nitrate $\mathrm{N}$ and $\mathrm{NH}_{4}{ }^{+}$, were detectable in all the soil locations, but Nitrite was below detectable limit $(<0.001)$ of the equipment used.

The amount of $\mathrm{N}$ in the soil is an indication of how suitable conditions in the soils environment are, and the content in this study sites could be classified as very low to high concentration. A value between 0.03 to $0.05 \%$ of nitrate $\mathrm{N}$ is considered low for soils [17]. In the study site, the concentration of $\mathrm{NH}^{+}$in the soil ranged from very low (Station $14 ; 0.050 \%$ ) to high (station 2;1.43\%) at the surface soil level and from $0.024 \%$ (Stations 5 and 10,) to 1.23\% (Stations 1, and 2), at the sub surface soil level of 15 to $30 \mathrm{~cm}$.

Apparently, the sorption site occupied by nitrogen-based organic substance was dominated by Nitrate-N. It varied from 0.09 (station 14) to 3.43\% (station 1 control) with a mean value of $0.818 \%$ on the surface soil, and from 0.04 (station 14) to $2.38 \%$ (station 1 control )(averaged, $0.624 \%$ ) in the subsurface soil.

\section{TOTAL ORGANIC CARBON (TOC)}

Soil organic $\mathrm{C}$ usually mixed up with fine clay particles to form soil colloids. It an important soil fraction due to its binding properties that enhanced most physical and chemical activities in the soil. Thus, there is increased contact with other colloids and with soil solution. This results in the strong friction and cohesion bonds between particles and soil water, and is why a clay soil holds together better than a sandy soil when wet. Total organic $\mathrm{C}$ reduced by $1.16 \%$ from the control. It ranged from 43.00 (Station 11) to $93.00 \mathrm{mg} \mathrm{kg}^{-1}$ (station 1 control) averaged $62.77 \mathrm{mg} \mathrm{kg}^{-1}$ at the surface level and from 38 (Station 7) to $88 \mathrm{mg} \mathrm{kg}^{-1}$ (Station 12), with a mean value of $56.23 \mathrm{mg} \mathrm{kg}^{-1}$ at the sub surface level. For an overall view, this site is high in organic $C$, and this could be attributed to decayed plant and animal remains in the fallow land. 


\section{TOTAL HYDROCARBON (THC) CONTENT}

The study area is at the proximity of industries for petroleum and non-petroleum hydrocarbon production activities thus necessitating the need for evaluating the total petroleum hydrocarbon content of the soil. Results as presented in Table 1, revealed that, other than the control sites, there was no trace of THC in locations 9, and 17. Total Petroleum Hydrocarbon (THC) concentrations ranged from $0.05 \mathrm{mg} / \mathrm{kg}$ (sample station 19) to $1.82 \mathrm{mg} \mathrm{kg}^{-1}$ (sample station 8) at the surface level (averaged $0.515 \mathrm{mg} / \mathrm{kg}$ ), and from $0.03 \mathrm{mg} / \mathrm{kg}$ (sample station 5 and 19) to $1.02 \mathrm{mg} / \mathrm{kg}$ (sample station 8) with average of $0.257 \mathrm{mg} \mathrm{kg}^{1}{ }^{1}$ at the subsurface soil. The ranges were lower at both surface levels. Although the THC result reveals that the area therefore is slightly contaminated by petroleum hydrocarbon there is need for continous monitoring of the toxicity of organic compound rise.

\section{Oil \& Grease}

Oil and grease belongs to the group of pollutants made up of oil mud and oil drilling additives limited in their release into the environment and occurs through (accidental) spillage and disposal of used product [18] and hence, constitutes the main environmental problems. Oil and grease were below detection limit in the control sites, locations 9 (subsurface), and 17. Locations affected ( $>1.0$ $\mathrm{mg} \mathrm{kg-}^{1}$ ) by oil and grease are 7, 8 and 9, while other soil locations are liable to pollution. As expected, the surface soils are more affected and the concentration of oil and grease was $56 \%$ more on the surface than the subsurface.

\section{Heavy Metals}

The mineral element originates from soil and dissolved in water for plant roots' absorption but those required in small quantity for optimum performance are regarded as traced elements. The concentration of these metals can however be increased to become potential pollutants if heavy metals - containing waste products from industrial or domestic activities are introduced into the environment [17]. Concern over the presence of heavy metals in an environment arises from the fact that they cannot be broken down into non toxic forms. Thus once aquatic ecosystems are contaminated by heavy metals, they remain a potential threat for many years [19]. Heavy metal such as iron, $\mathrm{Zn}$, cadmium, vanadium, lead and $\mathrm{Cu}$ accommodate by adsorption in the soil and remained for centuries.

Iron significantly $(\mathrm{p}<0.002)$ increased on the surface soil and it is beneficial to high-irondemand plants (shrubs, corn and beans) Analyses of the soil samples (Table 2) showed that concentration of metals (Cadmium, vanadium, lead and chromium; - were more significant in all the stations sampled (except for locations 2, 4, 15, 19 and 20) where the metals were below detectable limits. Cadmium, being more highly soluble than other heavy metals, was frequent in the study site. Ni concentrations were 1.26 and $1.069 \mathrm{mg} \mathrm{kg-}^{1}$ for surface and subsurface soils, but varied from, 0.790 to $1.84 \mathrm{mg} \mathrm{kg}^{1}{ }^{1}$ and 0.67 to $1.53 \mathrm{mg} \mathrm{kg}^{1}{ }^{1}$ for surface and subsurface layers. $\mathrm{Cu}$ on the other hand occurred in trace quantity in selected locations. The absence and minute concentrations of these substances at these stations indicated no pollution or toxicity in the study site related to metallic ions.

\section{Biological studies}

The soil environment is teeming with biological life and is one of the most abundant and diverse ecosystem on the earth [20] The microbial community in soil is important because of its relationship to soil fertility and the biochemical cycling of elements. Thus the need to enumerate and isolate major and minor members of the microbial community in soils. Micro organisms are predictably the first component of biota in an ecosystem, especially when demonstrating the effect of environmental pollution resulting from any contamination. As shown in Table 2, the soil microbes consist mainly substantially bacteria. Total heterotrophic bacterial counts (THBC) in the site was more in location 2 , and it varied from nil to $22 \times 10^{3} \mathrm{cfu} / \mathrm{g}$ soil (station 2) with a mean value of $3.18 \times 10^{3} \mathrm{cfu} / \mathrm{g}$ on the surface soil. 
The absence of fungi populations in the soil indicate that the soil have no potential to biodegrade petroleum hydrocarbons when they are inadvertently released into the environment. From the results, the effect of microbes on soil properties in these soils is far-ranging. That is, most of the stations sampled lack microbes (except bacteria) that could biodegrade the petroleum hydrocarbon discharged into the field.

\section{PARTICLE SIZE DISTRIBUTION AND MORPHOLOGICAL CHARACTERISTICS}

The particle size distribution is a fundamental index of soil physical properties. Knowledge of this property allows prediction of many other soil properties. In general, the soils of the humid tropics are subject to intense rain storms which often cause clay eluviations with resultant tendency toward coarse texture in the surface horizons. As shown in Table 3, the auger samples were generally sandy, whereas texture from the profile beyond 30 to $60 \mathrm{~cm}$ was loamy sand and $60-100$ $\mathrm{cm}$ was sandy loam. Moisture content varied from $29 \%$ to $38 \%$ between $0-15 \mathrm{~cm}$ and $15-30 \mathrm{~cm}$, but it increased to $42 \%$ at $60-100 \mathrm{~cm}$.

\section{Profile Study}

Modal profiles of the soil units have thus been described on the basis of field morphological characteristics as recorded at points of occurrence (Table 3). The pedon are classified (using the field description characteristics and laboratory data) according to USA system [13]. The characteristics of the surface soil $(0-30 \mathrm{~cm})$ were: Brown $(7.5 \mathrm{Y} \mathrm{R} \mathrm{5/2})$, sandy throughout 0-30 $\mathrm{cm}$, easily dugged up to $100 \mathrm{~cm}$ depth without restriction, with sub angular blocky structure and Clear wavy boundary. That of the subsurface $(30-60 \mathrm{~cm})$ were: Light brown $(7.5 \mathrm{Y} \mathrm{R} \mathrm{6/4)}$ colour, Moderate to medium sub angular blocky, and abrupt irregular boundary. At $60-100 \mathrm{~cm}$, the soil colour was Brown (7.5YR 5/4), weak sub angular blocky structure, and diffuse wavy boundary.

Generally, the inclusive graphic standard deviation showed that the grained-size variations of samples were extremely poorly sorted with over 4.0 phi. Also, the curves revealed that location 17 (Figure 2) and 30-60 cm depth of location 8, (L8_60) (Fig 3) have more finer grained soil than locations 10,12 and 20 , and $0-30 \mathrm{~cm}$ of location 8 .

The results of statistical analysis performed on Particle size distribution dataset over the selected stations are shown in Tables 4-6. Generally, peak distribution occurred in most cases (positive coefficient of skewness) with stations $1,2,5,10$, and 12 having a positively skewed distribution with an asymmetric tail [21] as evident in locations 9, 17, and 20 with $95 \%$ confidence level in most of the stations.

A normal Gaussian distribution has a kurtosis of 1.00 which is a curve with the sorting in the tails equal to the sorting in the central portion. If a sample curve is better sorted in the central part than in the tails, the curve is said to be excessively peaked (leptokurtic) or excessively flat (platykurtic). The results of this study revealed that locations 1 is leptokurtic; location 2, platykurtic; locations 5, 9, 12 and profile location 8, are very leptokurtic; locations 10 and 20 , mesokurtic; while location 17 is extremely leptokurtic.

\section{DEPOSITIONAL MAP AT DIFFERENT STRATA}

Kriged contour map indicated soils with high deposition of diagonalized metal-bound sediment in different strata of the field. Soil profiles were classified as strata, which comprised of surface and deep horizon. As expected, significant $(p<0.05)$ depositions were found on the surface of strata 1, 2,3,4,5 and 6, where grained-size variations of samples were extremely poorly sorted. Consequently, strata 7 and 8 contain well graded particles of different sizes extending from the south west quadrant to the north central quadrant (Fig 4). Soils with low clay content in each of the horizons were found in the western part of the field; whereas higher clay contents were found in the eastern part of the field, especially in the drainage areas. 


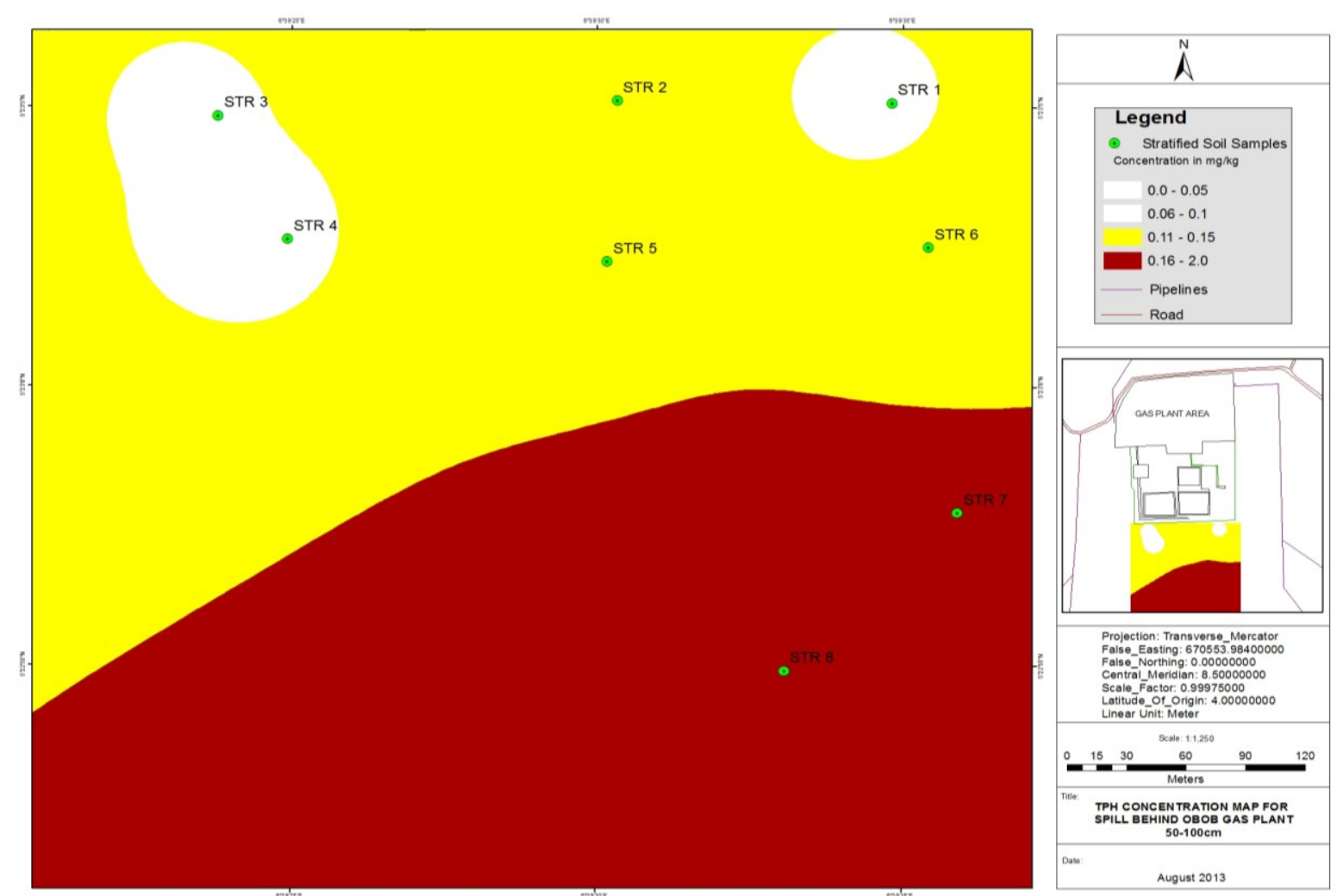

Fig 4. Depositional hydrology at different strata in the Subtidal hyper-space

\section{Conclusions}

The dynamics of soil properties including the prevailing environmental conditions and anthropogenic impacts, account for variations in the studied areas. This study provides valuable insight on the spatial and temporal patterns of soil properties in Onne. The results revealed that there is significant effect of ORP on the electron availability of nitrate and the tested heavy metals $(\mathrm{Cd}, \mathrm{Ni}, \mathrm{Pb}$, and $\mathrm{Cu})$ that were below detection limit in the soils. The least reduced conditions occurred in stations; 2 (control), 3, 6, 15, 18 and 19 with minimum values of 99 to $110 \mathrm{mv}$. The absence of fungi populations in the soil indicated that the soils have no potential to biodegrade petroleum hydrocarbons when they are inadvertently released into the environment.

Although the THC result reveals that the area is slightly contaminated by petroleum hydrocarbon, there is need for continous monitoring the increase in toxicity of organic compound.

Table 1. Summary of chemical and organic properties of the study site

\begin{tabular}{|c|c|c|c|c|c|c|c|c|c|}
\hline & $\mathrm{pH}$ & ORP (mv) & Cond. & Ammonium & Nitrate & Nitrite & TOC & THC & $\begin{array}{l}\text { Oil \& } \\
\text { Grease }\end{array}$ \\
\hline \multicolumn{10}{|c|}{ Surface ; 0-15 cm } \\
\hline mean & 4.4 & 132.682 & 68.727 & 0.258 & 0.818 & $<0.001$ & 62.773 & 0.515 & 0.600 \\
\hline sample variance & 0.2 & 329.370 & 2398.113 & 0.076 & 0.665 & $<0.000$ & 205.422 & 0.178 & 0.237 \\
\hline minimum & 4.0 & 102.000 & 18.000 & 0.050 & 0.090 & $<0.001$ & 43.000 & 0.05 & $<0.010$ \\
\hline maximum & 6.4 & 160.000 & 204.000 & 1.430 & 3.430 & $<0.001$ & 93.000 & 1.820 & 1.910 \\
\hline skewness & 3.5 & -0.277 & 1.203 & 3.969 & 1.892 & & 0.261 & 1.193 & 0.963 \\
\hline $\begin{array}{l}\text { kurtosis } \\
\text { coefficient of variation }\end{array}$ & 14.6 & -1.176 & 1.079 & 17.245 & 4.207 & & -0.890 & 3.041 & 1.276 \\
\hline$(\mathrm{CV})$ & 0.1 & 0.137 & 0.713 & 1.070 & 0.997 & 0.000 & 0.228 & 0.821 & 0.811 \\
\hline median & 4.3 & 137.500 & 44.500 & 0.200 & 0.450 & $<0.001$ & 63.000 & 0.515 & 0.540 \\
\hline mode & 4.3 & 120.000 & 40.000 & 0.210 & 0.240 & $<0.001$ & 70.000 & 0.001 & $<0.010$ \\
\hline \multicolumn{10}{|c|}{ Subsurface; $15-30 \mathrm{~cm}$} \\
\hline
\end{tabular}




\begin{tabular}{|c|c|c|c|c|c|c|c|c|c|}
\hline mean & 4.4 & 127.909 & 68.909 & 0.261 & 0.624 & $<0.001$ & 56.727 & 0.257 & 0.321 \\
\hline sample variance & 0.3 & 307.515 & 2641.801 & 0.097 & 0.414 & $<0.000$ & 221.160 & 0.089 & 0.137 \\
\hline minimum & 3.9 & 99.000 & 21.000 & 0.024 & 0.040 & $<0.001$ & 38.000 & 0.03 & $<0.010$ \\
\hline maximum & 6.6 & 169.000 & 201.000 & 1.230 & 2.380 & $<0.001$ & 88.000 & 1.020 & 1.220 \\
\hline skewness & 3.8 & 0.274 & 1.246 & 2.635 & 1.412 & & 0.749 & 1.102 & 1.232 \\
\hline $\begin{array}{l}\text { kurtosis } \\
\text { coefficient of variation }\end{array}$ & 16.4 & -0.301 & 0.860 & 6.426 & 1.527 & & -0.268 & 0.325 & 0.595 \\
\hline$(\mathrm{CV})$ & 0.1 & 0.137 & 0.746 & 1.191 & 1.031 & 0.000 & 0.262 & 1.160 & 1.155 \\
\hline median & 4.3 & 131.000 & 51.000 & 0.170 & 0.310 & 0.001 & 55.000 & 0.105 & 0.140 \\
\hline mode & 4.4 & 109.000 & 21.000 & 0.170 & 0.180 & 0.001 & 43.000 & 0.001 & 0.010 \\
\hline
\end{tabular}

Table 2. Summary of heavy metals and hydrocarbon degrading bacteria in soils of Onne

\begin{tabular}{|c|c|c|c|c|c|c|c|c|c|c|c|c|}
\hline & Iron & Zinc & $\mathrm{Cr}$ & Cd. & $\begin{array}{l}\text { Vanadium } \\
\text { Surface ( } 0\end{array}$ & $\begin{array}{c}\mathrm{Ni} \\
15 \mathrm{~cm})\end{array}$ & \multicolumn{5}{|c|}{ Surface $(0-15 \mathrm{~cm})$} & HUB \\
\hline Mean & 2.034 & $<0.001$ & $<0.001$ & $<0.001$ & $<0.001$ & 1.260 & $<0.001$ & 0.162 & 5.682 & 0.000 & 0.000 & 1.909 \\
\hline $\begin{array}{c}\text { Sample } \\
\text { variance }\end{array}$ & 1.111 & $<0.000$ & $<0.000$ & $<0.000$ & $<0.000$ & 0.077 & $<0.000$ & 0.014 & 33.751 & 0.000 & 0.000 & 2.182 \\
\hline Minimum & 0.880 & $<0.001$ & $<0.001$ & $<0.001$ & $<0.001$ & 0.790 & $<0.001$ & 0.001 & 0.000 & 0.000 & 0.000 & 0.000 \\
\hline Maximum & 4.350 & $<0.001$ & $<0.001$ & $<0.001$ & $<0.001$ & 1.840 & $<0.001$ & 0.410 & 22.000 & 0.000 & 0.000 & 5.000 \\
\hline skewness & 1.053 & -1.075 & -1.075 & -1.075 & -1.075 & 0.233 & -1.075 & 0.246 & 1.665 & & & 0.268 \\
\hline kurtosis & 0.408 & -2.211 & -2.211 & -2.211 & -2.211 & 0.206 & -2.211 & -0.395 & 2.401 & & & -0.741 \\
\hline$(\mathrm{CV})$ & 0.518 & 0.000 & 0.000 & 0.000 & 0.000 & 0.220 & 0.000 & 0.728 & 1.022 & & & 0.774 \\
\hline \multicolumn{13}{|c|}{ Subsurface $(15-30 \mathrm{~cm})$} \\
\hline $\begin{array}{c}\text { mean } \\
\text { sample }\end{array}$ & 1.623 & 0.001 & 0.001 & 0.001 & 0.001 & 1.069 & 0.001 & 0.098 & 3.182 & 0.000 & 0.000 & 0.682 \\
\hline variance & 0.948 & 0.000 & 0.000 & 0.000 & 0.000 & 0.043 & 0.000 & 0.005 & 21.870 & 0.000 & 0.000 & 0.894 \\
\hline minimum & 0.580 & 0.001 & 0.001 & 0.001 & 0.001 & 0.670 & 0.001 & 0.001 & 0.000 & 0.000 & 0.000 & 0.000 \\
\hline maximum & 3.890 & 0.001 & 0.001 & 0.001 & 0.001 & 1.530 & 0.001 & 0.230 & 18.000 & 0.000 & 0.000 & 3.000 \\
\hline skewness & 1.184 & -1.075 & -1.075 & -1.075 & -1.075 & -0.011 & -1.075 & 0.030 & 2.181 & & & 1.092 \\
\hline kurtosis & 0.457 & -2.211 & -2.211 & -2.211 & -2.211 & 0.456 & -2.211 & -0.756 & 4.536 & & & -0.006 \\
\hline (CV) & 0.600 & 0.000 & 0.000 & 0.000 & 0.000 & 0.193 & 0.000 & 0.716 & 1.470 & & & 1.387 \\
\hline
\end{tabular}


Table 3. Physical and morphological characteristics of surface and subsurface soils in Onne

\begin{tabular}{clllllc}
\hline $\begin{array}{c}\text { Sample } \\
\text { ID }\end{array}$ & DEPTH & Sand & Silt & Clay & Texture & $\begin{array}{c}\text { Moisture } \\
\text { content }\end{array}$ \\
\hline SS1C & $0-15$ & 86.70 & 7.96 & 5.34 & sandy & 0.32 \\
SS1C & $15-30$ & 92.90 & 1.46 & 5.64 & sandy & 0.32 \\
SS2 & $0-15$ & 90.90 & 3.46 & 5.64 & sandy & 0.32 \\
SS5 & $0-15$ & 90.90 & 3.46 & 5.64 & sandy & 0.34 \\
SS5 & $15-30$ & 87.38 & 7.28 & 5.34 & sandy & 0.31 \\
SS9 & $0-15$ & 86.90 & 5.46 & 7.64 & sandy & 0.32 \\
SS9 & $15-30$ & 86.90 & 7.46 & 5.64 & sandy & 0.34 \\
SS10 & $0-15$ & 85.38 & 9.28 & 5.34 & sandy & 0.29 \\
SS10 & $15-30$ & 84.90 & 7.46 & 7.64 & sandy & 0.32 \\
SS12 & $0-15$ & 91.38 & 3.28 & 5.34 & sandy & 0.31 \\
SS12 & $15-30$ & 86.90 & 7.46 & 5.64 & sandy & 0.32 \\
SS17 & $0-15$ & 89.38 & 5.28 & 5.34 & sandy & 0.38 \\
SS17 & $15-30$ & 89.38 & 5.28 & 5.34 & sandy & 0.31 \\
SS20 & $15-30$ & 88.90 & 5.46 & 5.64 & sandy & 0.32 \\
SS20 & $0-15$ & 91.38 & 3.28 & 5.34 & sandy & 0.32 \\
\hline
\end{tabular}

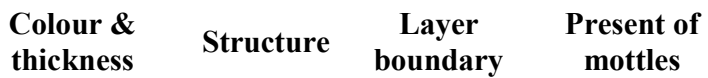

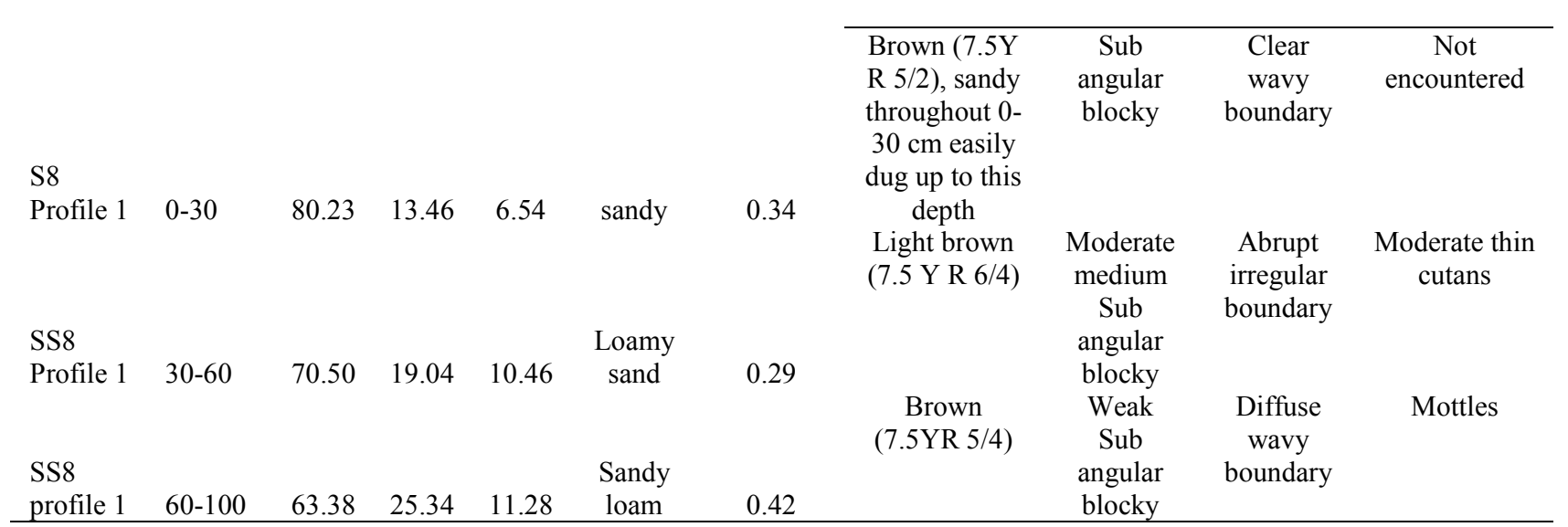

Table 4. Grain-size analysis in the phi scale (Locations 1,2,5, \&9).

\begin{tabular}{|c|c|c|c|c|c|c|c|c|c|c|c|c|}
\hline \multirow[b]{2}{*}{ phi size } & \multicolumn{2}{|c|}{ Location 1 (control) } & \multicolumn{3}{|c|}{ Location 2} & \multicolumn{3}{|c|}{ Location 5} & \multicolumn{3}{|c|}{ Location 9} & \multirow[b]{2}{*}{ cum } \\
\hline & $\begin{array}{c}\mathrm{Wt} \\
\text { retained }\end{array}$ & $\begin{array}{c}\% \\
\text { Retained }\end{array}$ & cum & $\begin{array}{c}\mathrm{Wt} \\
\text { retained }\end{array}$ & $\begin{array}{c}\% \\
\text { Retained }\end{array}$ & cum & $\begin{array}{l}\mathrm{Wt} \\
\text { retained }\end{array}$ & $\begin{array}{c}\% \\
\text { Retained }\end{array}$ & cum & $\begin{array}{c}\mathrm{Wt} \\
\text { retained }\end{array}$ & $\begin{array}{c}\% \\
\text { Retained }\end{array}$ & \\
\hline-1 & 27.53 & 28.4 & 28.4 & 13.77 & 13.9 & 13.9 & 29.7 & 32.5 & 32.5 & 19.73 & 22.3 & 22.3 \\
\hline 0 & 20.3 & 20.3 & 48.7 & 51.87 & 52.4 & 66.3 & 6.07 & 6.6 & 39.1 & 3.27 & 3.8 & 26.1 \\
\hline 1 & 38.1 & 39.3 & 88 & 31.33 & 31.7 & 98 & 15.27 & 16.5 & 55.6 & 13.1 & 14.8 & 40.9 \\
\hline 2 & 8.63 & 8.6 & 96.6 & 1.4 & 1.4 & 99.4 & 12.4 & 13.4 & 69 & 13.2 & 14.9 & 55.8 \\
\hline 3 & 3.3 & 3.4 & 100 & 0.6 & 0.6 & 100 & 28.33 & 31 & 100 & 39.03 & 44.2 & 100 \\
\hline $\begin{array}{c}\text { Median } \\
\text { phi }\end{array}$ & 20.3 & 20.9 & & 13.8 & 13.9 & & 15.3 & 16.7 & & 13.2 & 14.9 & \\
\hline deviation & 12.58 & 12.98 & & 19.52 & 19.73 & & 9.21 & 10.09 & & 11.91 & 13.49 & \\
\hline Skewness & 0.19 & 0.19 & & 0.84 & 0.84 & & 0.14 & 0.13 & & 1.0 & 1.0 & \\
\hline kurtosis & -1.42 & -1.42 & & -0.68 & -0.69 & & -2.37 & -2.36 & & 2.04 & 2.05 & \\
\hline $\mathrm{CV}$ & $72 \%$ & $72 \%$ & & $110 \%$ & $110 \%$ & & $56 \%$ & $56 \%$ & & $75 \%$ & $75 \%$ & \\
\hline
\end{tabular}


Table 5. Grain-size analysis in the phi scale (Locations 10,12,17, \&20).

\begin{tabular}{|c|c|c|c|c|c|c|c|c|c|c|c|c|}
\hline \multirow[b]{2}{*}{ phi size } & \multicolumn{3}{|c|}{ Location 10} & \multicolumn{3}{|c|}{ Location 12} & \multicolumn{3}{|c|}{ Location 17} & \multicolumn{3}{|c|}{ Location 20} \\
\hline & $\begin{array}{c}\mathrm{Wt} \\
\text { retained }\end{array}$ & $\begin{array}{c}\% \\
\text { Retained } \\
\end{array}$ & cum & $\begin{array}{c}\mathrm{Wt} \\
\text { retained }\end{array}$ & $\begin{array}{c}\% \\
\text { Retained } \\
\end{array}$ & cum & $\begin{array}{c}\mathrm{Wt} \\
\text { retained }\end{array}$ & $\begin{array}{c}\% \\
\text { Retained } \\
\end{array}$ & cum & $\begin{array}{c}\mathrm{Wt} \\
\text { retained }\end{array}$ & $\begin{array}{c}\% \\
\text { Retained } \\
\end{array}$ & cum \\
\hline-1 & 20.77 & 24.1 & 24.1 & 16.87 & 18.5 & 18.5 & 11 & 11.3 & 11.3 & 8.37 & 9 & 9 \\
\hline 0 & 3.03 & 3.5 & 27.6 & 3.33 & 3.7 & 22.2 & 5.2 & 5.4 & 16.7 & 2.6 & 2.8 & 11.8 \\
\hline 1 & 14.5 & 16.9 & 44.5 & 16.1 & 17.6 & 39.8 & 60 & 61.6 & 78.3 & 21.63 & 23.4 & 35.2 \\
\hline 2 & 12.47 & 14.5 & 59 & 16.67 & 18.3 & 58.1 & 18.03 & 18.5 & 96.8 & 23.77 & 25.4 & 60.6 \\
\hline 3 & 35.27 & 41 & 100 & 38.3 & 41.9 & 100 & 3.13 & 3.2 & 100 & 36.67 & 39.4 & 100 \\
\hline $\begin{array}{l}\text { median } \\
\text { phi }\end{array}$ & 14.5 & 16.9 & & 16.7 & 18.3 & & 11.0 & 11.3 & & 21.6 & 23.6 & \\
\hline deviation & 10.67 & 12.41 & & 11.26 & 12.32 & & 20.91 & 21.48 & & 1.0 & 1.0 & \\
\hline skewness & 0.73 & 0.72 & & 0.99 & 0.97 & & 1.0 & 1.0 & & 0.15 & 0.12 & \\
\hline kurtosis & 1.09 & 1.11 & & 2.52 & 2.50 & & 3.77 & 3.77 & & -0.97 & -1.02 & \\
\hline $\mathrm{CV}$ & $69 \%$ & $69 \%$ & & $69 \%$ & $69 \%$ & & $120 \%$ & $120 \%$ & & $72 \%$ & $72 \%$ & \\
\hline
\end{tabular}

Table 6. Grain-size analysis in the phi scale (Location 8: Profile)

\begin{tabular}{|c|c|c|c|c|c|c|}
\hline \multirow[b]{2}{*}{ phi size } & \multicolumn{3}{|c|}{ Location 8 ( Profile 0-30) } & \multicolumn{3}{|c|}{ Location 8 (Profile 30-60) } \\
\hline & $\begin{array}{c}\mathrm{Wt} \\
\text { retained }\end{array}$ & $\begin{array}{c}\% \\
\text { Retained } \\
\end{array}$ & cum & $\begin{array}{c}\mathrm{Wt} \\
\text { retained }\end{array}$ & $\begin{array}{c}\% \\
\text { Retained } \\
\end{array}$ & cum \\
\hline-1 & 28.97 & 33 & 33 & 32.83 & 33.5 & 33.5 \\
\hline 0 & 3.6 & 4.1 & 37.1 & 7.57 & 7.7 & 41.2 \\
\hline 1 & 10.9 & 12.4 & 49.5 & 19.5 & 19.9 & 61.1 \\
\hline 2 & 10.57 & 12 & 61.5 & 19.1 & 19.5 & 80.6 \\
\hline 3 & 33.83 & 38.5 & 100 & 19.07 & 19.4 & 100 \\
\hline $\begin{array}{c}\text { Median } \\
\text { phi }\end{array}$ & 10.9 & 12.4 & & 19.1 & 19.5 & \\
\hline deviation & 11.69 & 13.31 & & 8.01 & 8.18 & \\
\hline skewness & 0.45 & 0.45 & & 0.33 & 0.33 & \\
\hline kurtosis & -2.46 & -2.47 & & 2.05 & 2.05 & \\
\hline $\mathrm{CV}$ & $74 \%$ & $74 \%$ & & $46 \%$ & $46 \%$ & \\
\hline
\end{tabular}

\section{References}

[1] Schjanning, P., Thomsen, I.K., Maberg, J.P., de Jonge, H., Kristensen, K., Christensen, B. 1999. Turnover of organic matter in differently textured soils. I. Physical characteristics of structurally disturbed and intact soils. Geoderma 89, 177-198.

[2] Horn, R., Fleige, H. 2009. Risk assessment of subsoil compaction for arable soils in Northwest Germany at farm scale. Soil Till. Res. 102, 201-208.

[3] Ball B.C., Scott A., Parker J.P. 1999. Field $\mathrm{N}_{2} \mathrm{O}, \mathrm{CO}_{2}$ and $\mathrm{CH}_{4}$ fluxes in relation to tillage, compaction and soil quality in Scotland. Soil Till. Res. 53, 29-39.

[4] Shakoor, A and BD Cook. 1990. "The Effect of Stone Content, Size, and Shape on Engineering. Properties of a Compacted Silty Clay.” Bull. Assoc. Eng. Geol. XXVII(2):245253.

[5] Anonymous 1995. Biotechnology for the $21^{\text {st }}$ century: New Horizons. Biotechnology subcommittee (BRS) committee in Fundamental science and research national scienceand technology council .Washington DC.

[6] Schroth, MH, SJ Ahearn, JS Selker, and JD Istok. 2005. "Characterization of Miller-Similar Silica Sands for Laboratory Hydrologic Studies.” Soil Sci. Soc. Am. J. 60:1331-1339. 
[7] Edem, I. D and U.C. Udo-Inyang. 2013. Consequences of effluent discharge and sea water intrusions on soil's nutrient pools and biological spectra in Niger Delta. J.Wetlands Biodiversity, 3:51-66

[8] Kamann, PJ, RW Ritzi, DF Dominic, and CM Conrad. 2007. "Porosity and Permeability in Sediment Mixtures". Ground Water, 45(4):429-438.

[9] Gupta, P.K. 2004. Method in Environmental analysis Water, Soil, Air. Updesh puroline for Agro-bios (India), Jodhpur.

[10] Koltermann CE and SM Gorelick. 2003. "Fractional Packing Model for Hydraulic Conductivity Derived from Sediment Mixtures.” Water Resour. Res. 31(12):3283-3297.

[11] Marion, D. 2009. Acoustical, Mechanical, and Transport Properties of Sediments and Granular Materials. Ph.D. dissertation, 136 pp., Stanford University, Stanford, California.

[12] N.P.C. (National population commission) 2006. National Population census bulletin.

[13] Soil Survey Staff. 1975. "Soil Taxonomy: A Basic System of Soil Classification for Making and Interpreting Soil Surveys." USDA-SCS Agric. Handbook 436, U.S. Government Printing Office, Washington, D.C.

[14] Troeh, I.O., and Thompson, U.C. 1993. Soil $\mathrm{pH}$ ranges for $\mathrm{pH}$ classes and associated conditions. National soil survey manual.

[15] Gee, GW and D Or. 2002. "Particle-Size Analysis." In JH Dane and GC Topp (eds.), Methods of Soil Analysis Part 4 Physical Methods. Pp. 255-293, Soil Science Society of America, Inc. Madison, Wisconsin.

[16] Akinrinde, E.A. 2006. Issues of optimum nutrient supply for sustainable crop production in tropical developing countries. Pakistan journal of nutrition 5 (4): 377-387.

[17] Nunez-Delgado, B., Morrison L, Gulson, L 2002. Threshold of concern: a technique for evaluating environmental impact and amenity values. Journal of forestry 84-86

[18] Odu, C.T 2000. Rehabilitation of soils after oil spills. In Akoroda, M. O. (ed), Agronomy in Nigeria. Department of Agronomy, University of Ibadan, Nigeria. P.223-227.

[19] Isirimah, N.O, Effiong, G.S .and Eshiet, U. 2006. Influence of liming on extractable P growth and yield evaluation of okra (Abelmoscuhus esculentus(L) Moench). NJAFE 3 (1\&2):131134

[20] Brady, N. and R. Weil. 2002. The nature and properties of soils, $13^{\text {th }}$ Edition, prentice Hall. Upper Saddle River, New Jersey. 960 p.

[21] Dunn, A.J and G.R. Mehuys. 1984. "Relationship between Gravel Content of Soils and Saturated Hydraulic Conductivity in Laboratory Tests." In JD Nichols (ed.), Erosion and Productivity of Soils Containing Rock Fragments. Special Publication, Vol. 13, Soil Science Society of America, Madison, Wisconsin. 